\title{
OPTIMASI WAKTU AKTIVASI DAN KARAKTERISASI ARANG AKTIF DARI BATANG TANAMAN GUMITIR DENGAN AKTIVATOR NaOH
}

\author{
E. Sahara, I K. Y. Resyana*, dan A. A. I. A. M. Laksimawti \\ Program Studi Kimia Fakultas Matematika dan Ilmu Pengetahuan Alam Universitas Udayana \\ Jalan Kampus Unud-Jimbaran, Jimbaran-Bali, Indonesia \\ *Email: resyana93@gmail.com
}

\begin{abstract}
ABSTRAK
Batang tanaman gumitir dapat digunakan sebagai bahan dasar pembuatan arang aktif. Salah satu aktivator yang dapat digunakan adalah $\mathrm{NaOH}$ dengan waktu aktivasi selama 24 jam. Tujuan dari penelitian ini adalah untuk memperoleh waktu aktivasi yang efektif melalui aktivasi dengan aktivator $\mathrm{NaOH}$ 2,5\% dalam beberapa variasi waktu aktivasi arang dilanjutkan dengan karakterisasi terhadap arang aktif yang terbentuk. Karakterisasi yang dilakukan meliputi kadar air, kadar zat mudah menguap, kadar abu, kadar karbon, daya serap terhadap metilen biru dan daya serap terhadap iodin. Hasil penelitian menunjukkan bahwa aktivasi selama 28 jam menghasilkan arang aktif dengan karakteristik yang sesuai dengan SNI 06-3730-1995 yaitu: kadar air (8,40 $\pm 0,72) \%$, kadar zat mudah menguap $(9,58 \pm 0,95) \%$, kadar abu $(4,93 \pm 0,83) \%$, kadar karbon $77,09 \%$, daya serap terhadap iodin $(758,6874 \pm$ $1,21) \mathrm{mg} / \mathrm{g}$ dan daya serap terhadap metilen biru $124,6226 \mathrm{mg} / \mathrm{g}$. Hasil analisis dengan spektrofotometer FTIR terhadap arang aktif tersebut menunjukkan adanya gugus fungsi $\mathrm{OH}, \mathrm{CH}$ alifatik, $\mathrm{C}=\mathrm{O}$ dan $\mathrm{C}=\mathrm{C}$.
\end{abstract}

Kata kunci: arang aktif, natrium hidroksida, batang tanaman gumitir

\begin{abstract}
The stems of marigold plant can be used as the raw material for making activated carbon. One of the activators that can be used is $\mathrm{NaOH}$ with an activated time of 24 hours. The purpose of this study was to obtain an effective activation time through activation with a $2.5 \% \mathrm{NaOH}$ activator in several variations of activation time followed by characterizing the activated carbon formed. Characterization which was carried out including the determination of water, volatile matter, ash, carbon contents, as well as the absorption capacity of methylene blue and iodine. The results of the study showed that the activation for 28 hours produced an activated carbon with characteristics in accordance with SNI 06-3730-1995, namely: water content $(8.40 \pm 0.72) \%$, volatile matter content $(9.58 \pm 0.95) \%$, ash content $(4.93 \pm 0.83) \%$, carbon content of $77.09 \%$, absorption of iodine $(758.66874 \pm 1.21) \mathrm{mg} / \mathrm{g}$ and absorption of methylene blue $124.6226 \mathrm{mg} / \mathrm{g}$. The results of the analysis with FTIR spectrophotometer on this activated charcoal showed the presence of $\mathrm{OH}, \mathrm{CH}$ aliphatic, $\mathrm{C}=\mathrm{O}$ and $\mathrm{C}=\mathrm{C}$ functional groups.
\end{abstract}

Keywords: activated carbon, sodium hydroxide, marigold plant stems

\section{PENDAHULUAN}

Tanaman gumitir (Tagetes erecta) merupakan tanaman herbal dari keluarga bunga matahari. Memiliki bentuk bunga yang unik dan warna kuning yang mencolok, membuat tanaman ini termasuk sebagai tanaman ornamental (Priyanka et al., 2013). Siaka et al., (2017) telah melakukan penelitian mengenai pembuatan dan karakterisasi arang aktif dari tanaman gumitir pada berbagai suhu dan waktu karbonisasi. Pada hasil penelitian tersebut didapatkan bahwa suhu optimum karbonisasi adalah sebesar $300^{\circ} \mathrm{C}$ dan waktu karbonisasi optimum selama 90 menit. Sahara et al., (2017), telah melaporkan bahwa arang aktif dapat dibuat dari batang gumitir dengan cara karbonisasi pada suhu $300^{\circ} \mathrm{C}$ selama 90 menit dengan aktivator kimia $\mathrm{H}_{3} \mathrm{PO}_{4}$. Pada penelitian tersebut diperoleh data bahwa untuk mendapatkan arang aktif yang memenuhi standar SNI 06-37301995, untuk setiap 1 gram arang aktif 
membutuhkan 3,75 $\mathrm{g} \mathrm{H}_{3} \mathrm{PO}_{4}(25 \mathrm{~mL}$ larutan $\mathrm{H}_{3} \mathrm{PO}_{4} 15 \%$ ) dengan waktu aktivasi selama 24 jam. Selain dengan $\mathrm{H}_{3} \mathrm{PO}_{4}$, aktivasi arang aktif dari batang tanaman gumitir juga dapat dilakukan dengan menggunakan $\mathrm{NaOH}$ (Sahara et al., 2017) yaitu, untuk setiap 1 gram arang membutuhkan $0,3125 \mathrm{~g} \mathrm{NaOH}(12,5 \mathrm{~mL} \mathrm{NaOH}$ 2,5\%) dengan waktu aktivasi selama 24 jam.

Pari et al., (2006) telah melakukan penelitian mengenai variasi waktu aktivasi arang aktif dari kulit kayu Acia mangium dengan menggunakan aktivator $\mathrm{H}_{3} \mathrm{PO}_{4}$. Variasi waktu yang digunakan oleh Pari et al., (2006) adalah 30, 60 dan 90 menit dimana waktu aktivasi optimum yang didapatkan adalah 60 menit. Penentuan waktu aktivasi optimum arang aktif dari bahan kulit singkong dengan menggunakan aktivator $\mathrm{NaOH}$ juga telah dilakukan oleh Utomo (2014) dimana aktivasi dilakukan selama 18, 20, 22, 24 dan 26 jam. Dalam penelitian ini diperoleh waktu aktivasi optimum selama 22 jam. Berbagai penelitian di atas menggambarkan bahwa waktu aktivasi dapat mempengaruhi kualitas arang aktif yang dihasilkan.

Berdasarkan penelitian yang tersebut dan dengan melihat lamanya waktu yang diperlukan untuk aktivasi arang dari batang gumitir, maka dalam penelitian ini akan dilakukan optimasi waktu aktivasi dan karakterisasi arang aktif dari batang tanaman gumitir dengan aktivator $\mathrm{NaOH}$ dan $\mathrm{H}_{3} \mathrm{PO}_{4}$. Dengan demikian, akan diperoleh waktu aktivasi optimum yang diperlukan untuk mendapatkan arang aktif yang memenuhi standar SNI 06-3730-1995.

\section{MATERI DAN METODE}

\section{Bahan}

Sampel tanaman gumitir yang diperoleh dari "Perkebunan Bali Gemitir" di daerah Mayungan, Baturiti-Tabanan. Larutan indikator amilum, metilen biru, $\mathrm{I}_{2}, \mathrm{~K}_{2} \mathrm{Cr}_{2} \mathrm{O}_{7}, \mathrm{Na}_{2} \mathrm{~S}_{2} \mathrm{O}_{3} .5 \mathrm{H}_{2} \mathrm{O}, \mathrm{KI}$, dan $\mathrm{NaOH}$. Kertas saring Whatman no. 12, kertas tisu dan aquades.

\section{Peralatan}

Gelas beaker, gelas ukur, cawan porselin, labu erlenmeyer, kaca arloji, pipet volume, pipet mikro, buret, corong, batang pengaduk, desikator, ayakan 250 dan $150 \mu \mathrm{m}$, mortar, botol semprot, pengaduk magnet, oven, tanur, Spektrofotometer Shimadzu UV-Vis 1800 dan Spektrofotometer Shimadzu IR Prestige-21.

\section{Cara Kerja \\ Penyiapan bahan}

Sampel tanaman gumitir (Tagetes erecta) dipisahkan antara batang dengan akar, daun dan bunganya. Setelah dipisah batang tanaman gumitir dicuci dengan air kran yang mengalir dan dibilas dengan aquades. Sampel kemudian dipotong kecil $( \pm 5 \mathrm{~cm})$ dan dijemur hingga kering.

\section{Karbonisasi batang gumitir (Tagetes erecta)}

Sebanyak $500 \mathrm{~g}$ sampel kering dikarbonisasi dalam tanur dengan suhu $300{ }^{\circ} \mathrm{C}$ selama 90 menit. Arang hasil karbonisasi digerus lalu diayak dengan ayakan ukuran $150-250 \mu \mathrm{m}$.

\section{Aktivasi arang batang gumitir}

Lima buah gelas beaker $500 \mathrm{~mL}$ dimasukkan masing-masing 11 gram serbuk arang hasil karbonisasi, lalu 5 buah gelas beker ditambahkan masing-masing $137,5 \mathrm{~mL}$ larutan $\mathrm{NaOH}$ dengan konsentrasi 2,5\%. Masing-masing campuran kemudian diaduk dengan pengaduk magnetik selama 12 jam;16 jam; 20 jam; 24 jam; $28 \mathrm{jam}$ dan $36 \mathrm{jam}$. Arang kemudian disaring dan dibilas dengan akuades hingga didapatkan $\mathrm{pH}$ netral. Arang yang sudah memiliki $\mathrm{pH}$ netral kemudian dikeringkan ke dalam oven pada suhu $105{ }^{\circ} \mathrm{C}$ selama 1 jam. Pengulangan proses aktivasi dilakukan sebanyak tiga kali.

\section{Karakterisasi arang aktif}

Prosedur analisis arang aktif yang dilakukan pada penelitian ini diadarkan pada Standar Nasional Indonesia 06-3730-1995 mengenai arang aktif teknis.

\section{Kadar air}

Sebanyak 5,0 g arang aktif ditempatkan pada gelas arloji lalu dikeringkan dalam oven pada suhu $105{ }^{\circ} \mathrm{C}$ hingga massanya konstan, kemudian ditentukan kadar airnya dalam persen $(\%)$. 


\section{Kadar zat mudah menguap.}

Sebanyak 4,0 g arang aktif yang sudah dihilangkan kadar airnya ditempatkan dalam cawan porselin dipanaskan dalam tanur pada suhu $900^{\circ} \mathrm{C}$ selama 15 menit, lalu didinginkan dalam desikator dan ditimbang.

\section{Kadar abu}

Sebanyak 2,5 g arang aktif diletakkan di dalam cawan porselin, kemudian dipanaskan dalam oven pada suhu $105{ }^{\circ} \mathrm{C}$ sampai diperoleh massa konstan. Arang aktif dalam cawan lalu dimasukkan ke dalam tanur dipanaskan pada suhu $650{ }^{\circ} \mathrm{C}$ selama 4 jam, lalu didinginkan dalam desikator dan ditimbang.

\section{Kadar karbon}

Kadar karbon terikat diketahui dengan cara selisih dari jumlah total kadar air, kadar zat mudah menguap dan kada abu dengan presentase total $(100 \%)$.

\section{Daya serap terhadap metilen biru}

Sebanyak 1 gram arang aktif dimasukkan ke dalam gelas beaker dan ditambahkan $50 \mathrm{~mL}$ larutan metilen biru 5000 ppm, selanjutnya diaduk dengan pengaduk magnetik selama 30 menit. Larutan disaring dengan kertas saring whatman no. 12, kemudian absorbansi dari filtratnya diukur dengan spektrofotometer UVVis pada $\lambda_{\max }$ metilen biru.

\section{Daya serap terhadap iodin}

Sebanyak 1,0 g arang dimasukkan ke dalam labu Erlenmeyer bertutup, kemudian ditambahkan $25 \mathrm{~mL}$ larutan iodium 0,125 M. Larutan diaduk selama 15 menit lalu labu ditutup dan disimpan ditempat yang gelap selama 2 jam. Larutan kemudian disaring, filtratnya dimasukkan ke dalam labu erlenmeyer yang bersihdan dititrasi dengan larutan $\mathrm{Na}_{2} \mathrm{~S}_{2} \mathrm{O}_{3}$ $0,1 \mathrm{~N}$ hingga larutan berwarna kuning muda. Sebanyak $1 \mathrm{~mL}$ indikator amilum ditambahkan dan titrasi dilanjutkan sampai warna biru tepat hilang. Volume larutan $\mathrm{Na}_{2} \mathrm{~S}_{2} \mathrm{O}_{3}$ yang digunakan dicatat dan dihitung daya serap arang aktif terhadap iodin dalam $\mathrm{mg} / \mathrm{g}$.

\section{Penentuan gugus fungsi}

Sebanyak $0,3 \mathrm{~g}$ arang aktif ditambahkam dengan serbuk $\mathrm{KBr}$. Campuran kemudian dimampatkan dalam sebuah cetakan menggunakan pompa hidrolik sehingga membentuk pellet. Kemudian pellet dianalisis dengan menggunakan FTIR.

\section{HASIL DAN PEMBAHASAN}

\section{Karbonisasi dan Aktivasi Batang Tanaman Gumitir (Tagetes Erecta)}

Sebanyak 910,38 gram sampel batang tanaman gumitir yang dikarbonisasi dalam tanur dengan suhu $300 \quad{ }^{\circ} \mathrm{C}$ selama 90 menit menghasilkan arang sebanyak 339,66 gram dengan presentase rendemen sebesar 37,31\%. Arang hasil karbonisasi kemudian diaktivasi secara kimia dengan cara perendaman ke dalam larutan natrium hidroksida $(\mathrm{NaOH})$ sebesar $0,3125 \mathrm{~g} \mathrm{NaOH} / \mathrm{g}$ arang (12,5 mL NaOH 2,5\%). Perendaman dengan aktivator ini dimaksudkan untuk menghilangkan atau membatasi pembentukan lignin karena lignin dapat membentuk senyawa tar yang dapat menutup pori sehingga mengurangi daya serap arang aktif.

\section{Karakterisasi Arang Aktif Rendemen $\mathrm{NaOH}$}

Pada Tabel 1 dapat dilihat bahwa, nilai rendemen tertinggi yang dihasilkan adalah $89,76 \% \pm 0,20 \%$ pada waktu aktivasi 12 jam, sedangkan nilai rendemen terendah terdapat pada waktu aktivasi 36 jam sebesar $81,08 \% \pm$ $0,43 \% . \%$.

Tabel 1. Rendemen Hasil Aktivasi Arang Batang Gumitir pada Berbagai Waktu Aktivasi Dengan Larutan $\mathrm{NaOH}$

\begin{tabular}{cc}
\hline $\begin{array}{c}\text { Waktu Aktivasi } \\
\text { (jam) }\end{array}$ & Rendemen $(\%)$ \\
\hline 12 & $89,76 \pm 0,20$ \\
16 & $88,84 \pm 0,55$ \\
20 & $87,53 \pm 0,14$ \\
24 & $86,09 \pm 0,34$ \\
28 & $82,47 \pm 0,10$ \\
36 & $81,08 \pm 0,43$ \\
\hline
\end{tabular}


Hubungan antara waktu aktivasi dan rendemen arang aktif dapat dilihat pada Gambar 1.

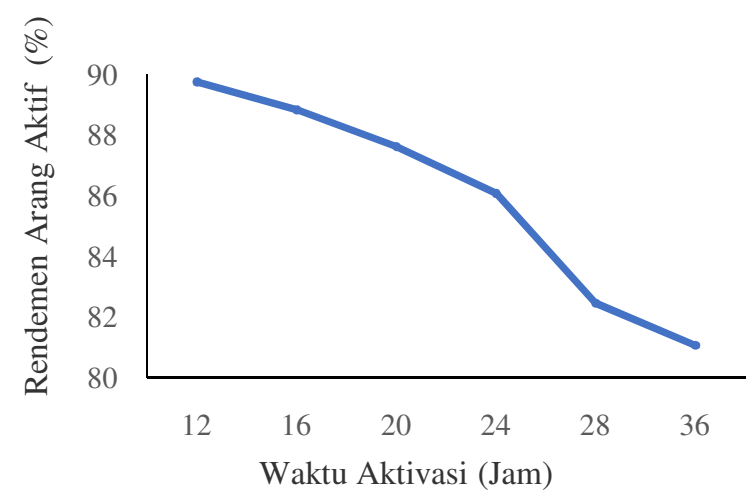

Gambar 1. Hubungan antara waktu aktivasi dan rendemen arang aktif
Pada Gambar 1 dapat dilihat bahwa semakin lama waktu aktivasi yang dilakukan semakin kecil rendemen arang aktif yang dihasilkan. Semakin menurunnya rendemen arang aktif dapat disebabkan karena semakin lama waktu aktivasi. Semakin lama waktu aktivasi, arang yang bereaksi dengan aktivator juga akan semakin lama, sehingga semakin banyak pengotor yang dibersihkan pada pori-pori arang dan menyebabkan rendahnya rendemen arang aktif yang dihasilkan.

Kadar Air, Kadar Zat Mudah Menguap, Kadar Abu Total dan Kadar Karbon

Hasil penentuan kadar air, kadar zat mudah menguap, kadar abu dan kadar karbon disajikan pada Tabel 2.

Tabel 2. Hasil Penentuan Kadar Air Kadar Zat Mudah Menguap dan Kadar Abu Total Arang Aktif dan Kadar Karbon dengan Aktivator $\mathrm{NaOH}$.

\begin{tabular}{ccccc}
\hline $\begin{array}{c}\text { Waktu Aktivasi } \\
(\mathbf{j a m})\end{array}$ & $\begin{array}{c}\text { Kadar air } \\
(\boldsymbol{\%})\end{array}$ & $\begin{array}{c}\text { Kadar zat } \\
\text { mudah } \\
\text { menguap }(\boldsymbol{\%})\end{array}$ & $\begin{array}{c}\text { Kadar abu } \\
\text { total }(\boldsymbol{\%})\end{array}$ & $\begin{array}{c}\text { Kadar } \\
\text { karbon } \\
(\boldsymbol{\%})\end{array}$ \\
12 & $10,20 \pm 0,40$ & $10,50 \pm 0,25$ & $9,07 \pm 0,61$ & 70,23 \\
16 & $8,87 \pm 0,61$ & $10,58 \pm 0,38$ & $7,33 \pm 1,01$ & 72,82 \\
20 & $9,47 \pm 0,81$ & $14,83 \pm 0,88$ & $8,40 \pm 1,06$ & 67,30 \\
24 & $10,53 \pm 0,64$ & $12,50 \pm 0,66$ & $6,40 \pm 0,80$ & 70,57 \\
28 & $8,40 \pm 0,72$ & $9,58 \pm 0,95$ & $4,93 \pm 0,83$ & 77,09 \\
36 & $8,53 \pm 0,95$ & $13,33 \pm 0,14$ & $6,53 \pm 0,92$ & 71,61 \\
SNI 06-3730-1995 & 15 & 25 & 10 & 65 \\
\hline
\end{tabular}

Dari data pada Tabel 2 dapat diketahui bahwa arang aktif yang diaktivasi dengan larutan $\mathrm{NaOH} 2,5 \%$ memiliki kadar air paling rendah pada waktu aktivasi 28 jam yakni $8,40 \%$ $\pm 0,72$. Penentuan kadar air bertujuan untuk mengetahui sifat higroskopis dari arang aktif. Sifat higroskopis arang aktif dapat mempengaruhi kemampuan penyerapan dari arang aktif karena semakin tinggi kadar air yang terikat pada arang aktif maka pori-pori dari arang aktif akan tertutup dan mengakibatkan berkurangnya kemampuan adsorpsi (Risfiandi, dkk 2016).

Kadar zat mudah menguap terendah sebesar $9,58 \% \pm 0,95 \%$ pada waktu aktivasi selama 28 jam. Rendahnya kadar zat mudah menguap pada arang aktif disebabkan oleh kandungan nitrogen dan sulfur dalam arang aktif yang telah tereduksi saat aktivasi sehingga senyawa nitrogen dan sulfur dalam arang aktif berkurang. Berkurangnya senyawa nitrogen dan sulfur pada arang aktif mengakibatkan rendahnya kadar zat mudah menguap pada arang aktif saat dipanaskan dalam suhu $900{ }^{\circ} \mathrm{C}$ (Pari, 1996). Selain akibat dari pengaruh nitrogen dan sulfur, menurut Sudrajat (2002) rendahnya kadar zat mudah menguap arang aktif juga dapat disebabkan oleh senyawa-senyawa hidrokarbon yang menempel pada permukaan arang terekstraksi pada saat proses aktivasi.

Hasil dari penentuan kadar abu dengan kadar abu terendah $4,93 \% \pm 0,83 \%$ yang 
dihasilkan pada waktu aktivasi selama 28 jam. Kadar abu yang terdapat pada arang aktif menunjukkan sisa dari hasil akhir proses pembakaran yang tidak habis selama proses pemanasan. Tinggi rendahnya kadar abu pada arang dapat disebabkan akibat adanya reaksi oksidasi di dalam tanur saat proses karbonisasi berlangsung pada suhu tinggi, sehingga menyebabkan terbentuknya oksida logam (Pari, 2004). Hubungan antara waktu aktivasi arang aktif dengan kadar air, kadarzat mudah menguap dan kadar abu disajikan pada Gambar 2.
Penentuan kadar karbon pada arang aktif bertujuan untuk mengetahui kandungan karbon murni pada arang aktif. Pada Tabel 2 diketahui bahwa kadar karbon arang aktif tertinggi dari arang aktif dengan aktivator $\mathrm{NaOH}$ didapatkan pada waktu aktivasi selama 28 jam. Tinggi rendahnya kadar karbon yang dihasilkan selain dipengaruhi oleh kadar air, kadar abu dan kadar zat mudah menguap juga dipengaruhi oleh kandungan selulosa dan lignin yang dapat dikonversi menjadi atom karbon (Pari, 2004).

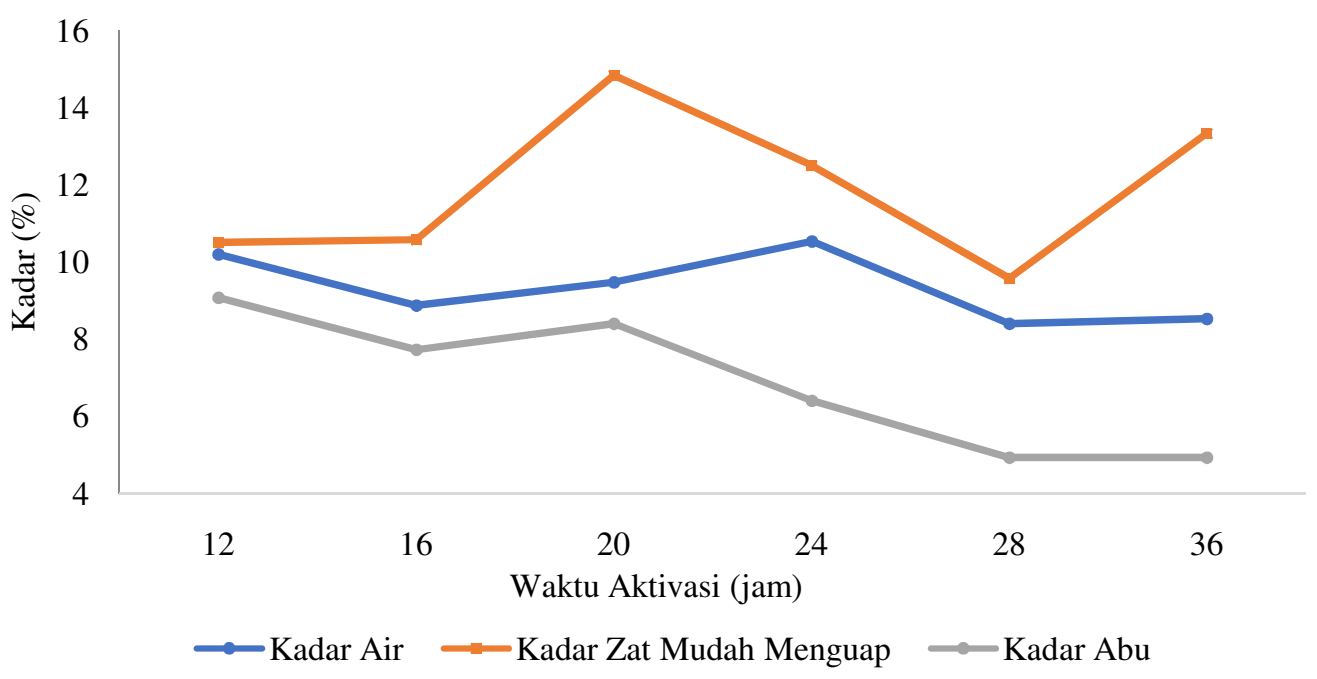

Gambar 2. Grafik hubungan antara waktu aktivasi arang aktif dengan kadar air, kadar zat mudah menguap dan kadar abu

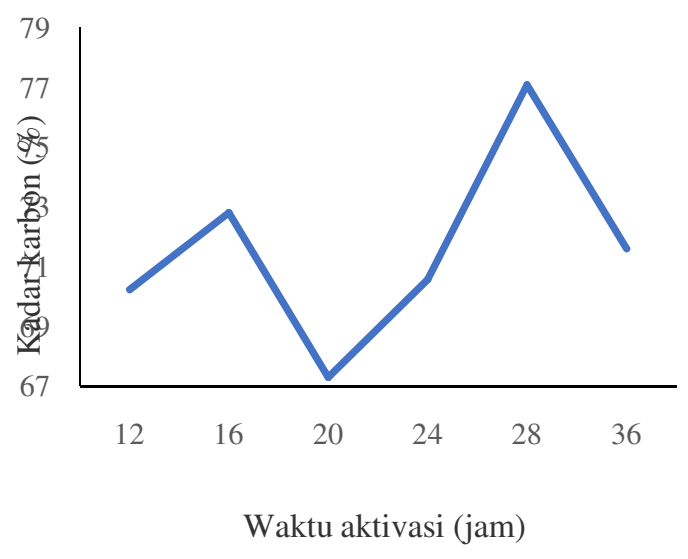

Gambar 3. Grafik hubungan antara waktu aktivasi arang aktif dengan kadar karbon

\section{Daya serap terhadap iodin}

Daya serap arang aktif terhadap iodin menunjukkan kemampuan arang aktif dalam menyerap zat yang mempunyai ukuran molekul yang lebih kecil dari 10.

Tabel 3. Hasil Penentuan Daya Serap Arang Aktif dengan Aktivator $\mathrm{NaOH}$ Terhadap Iodin

\begin{tabular}{c|c}
\hline $\begin{array}{c}\text { Waktu Aktivasi } \\
\text { (jam) }\end{array}$ & Daya serap iod (mg/g) \\
\hline 12 & $669,2267 \pm 0,93$ \\
16 & $682,7875 \pm 2,19$ \\
20 & $701,4083 \pm 1,40$ \\
24 & $721,4458 \pm 3,71$ \\
28 & $758,6874 \pm 1,21$ \\
36 & $729,9466 \pm 2,13$ \\
\hline
\end{tabular}


Daya serap terhadap iodin dari arang aktif dengan aktivator $\mathrm{NaOH}$ pada variasi waktu terbesar adalah 758,6874 $\pm 1,21 \mathrm{mg} / \mathrm{g}$ dengan waktu aktivasi 28 jam. Grafik hubungan antara daya serap iodin dengan waktu aktivasi arang aktif telah disajikan pada Gambar 4.

Pada penelitian ini, diketahui bahwa semakin lama waktu aktivasi maka semakin tinggi daya serap arang aktif terhadap iodin, seperti yang terlihat pada Gambar 4. Pada arang aktif dengan aktivator $\mathrm{NaOH}$ semakin lama waktu aktivasi, daya serap terhadap iod juga semakin meningkat. Hal ini dapat disebabkan karena pada waktu aktivasi optimum pembentukan pori dalam arang aktif meningkat dan diikuti dengan meningkatnya luas permukaan serta daya serap arang secara simultan. Setelah melewati waktu aktivasi optimum dinding pori arang aktif mulai rusak atau erosi sehingga akibatnya luas permukaan pori menurun kembali dan diikuti dengan menurunnya daya serap arang (Pari, 1996).

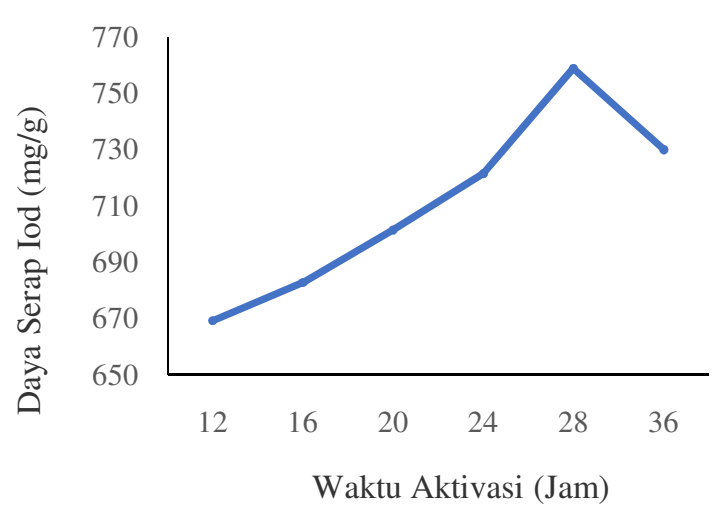

Gambar 4. Grafik hubungan antara daya serap iodin dengan waktu aktivasi arang aktif

\section{Daya serap terhadap metilen biru}

Penentuan daya serap terhadap metilen biru bertujuan untuk mengetahui kemampuan arang aktif untuk menyerap larutan berwarna dengan ukuran molekul $15 \square$ atau $15 \mathrm{~nm}$. Hasil penentuan daya serap arang aktif terhadap metilen biru telah disajikan pada Tabel 4 .
Tabel 4. Hasil Penentuan Daya Serap terhadap Metilen Biru

\begin{tabular}{c|c}
\hline $\begin{array}{c}\text { Waktu Aktivasi } \\
\text { (jam) }\end{array}$ & $\begin{array}{c}\text { Daya serap metilen biru } \\
\text { (mg/g) }\end{array}$ \\
\hline 12 & 124,5872 \\
16 & 124,5894 \\
20 & 124,5861 \\
24 & 124,5966 \\
28 & 124,6092 \\
36 & 124,5930 \\
\hline
\end{tabular}

Perbedaan daya serap arang aktif terhadap metilen biru yang tidak terlalu besar ini dapat disebabkan oleh penyimpanan arang aktif yang kurang baik, sehingga menyebabkan kadar air yang terdapat pada arang aktif meningkat dan mengurangi kemampuan arang aktif untuk menyerap metilen biru. Hubungan daya serap terhadap metilen biru yang dihasilkan diberbagai waktu aktivasi ditunjukkan pada Gambar 6.

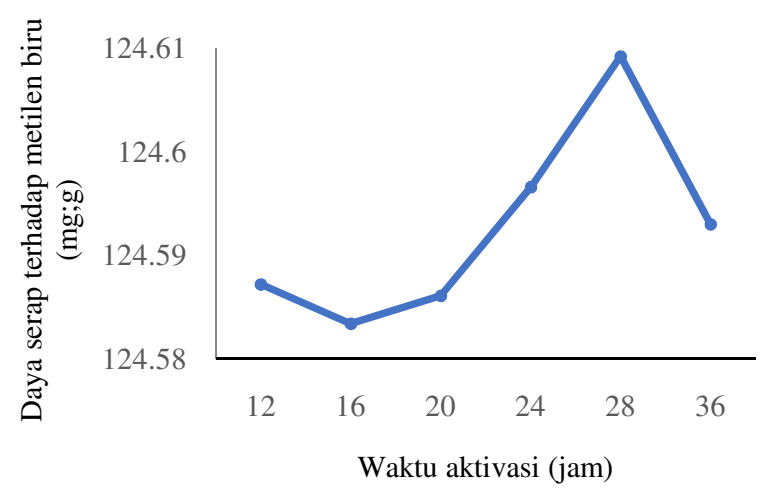

Gambar 6. Grafik hubungan antara daya serap terhadap metilen biru dengan waktu aktivasi arang aktif.

\section{Identifikasi gugus fungsi}

Arang aktif yang diidentifikasi gugus fungsinya adalah arang aktif yang menujukkan karakteristik paling baik sesuai dengan Standar Nasional Indonesia (SNI) 06-3730-1995 mengenai arang aktif, dalam hal ini arang aktif yang dihasilkan dengan waktu aktivasi 28 jam dengan aktivator $\mathrm{NaOH}$. Spektra inframerah hasil analisis arang aktif dengan aktivator $\mathrm{NaOH}$ disajikan pada Gambar 7. 
Spektra inframerah arang aktif yang dihasilkan dengan waktu aktivasi 28 jam menunjukkan adanya serapan-serapan karakteristik pada bilangan gelombang: 3311,78 $\mathrm{cm}^{-1}$ yang diduga adalah vibrasi gugus $\mathrm{O}-\mathrm{H}$. Serapan pada daerah $2920,11 \mathrm{~cm}^{-1}$ dan 2872,32 $\mathrm{cm}^{-1}$ diduga disebabkan oleh vibrasi dari $\mathrm{C}-\mathrm{H}$ alifatik, hal ini diperkuat dengan munculnya serapan pada daerah $1459,17 \mathrm{~cm}^{-1}$. Serapan pada daerah $1690,29 \mathrm{~cm}^{-1}$ yang diduga ikatan rangkap $\mathrm{C}=\mathrm{O}$.Serapan pada daerah $1651,37 \mathrm{~cm}^{-1}$ yang diduga disebabkan oleh vibrasi dari ikatan rangkap $\mathrm{C}=\mathrm{C}$.Terdapat serapan pada daerah $981,34 \mathrm{~cm}^{-1}$ yang merupakan tekukan bidang keluar dari C-H. Serapan pada daerah 723,03 $\mathrm{cm}^{-1}$ merupakan pita yang dihasilkan dari getaran (rocking) gugus $\mathrm{C}-\mathrm{H}$.

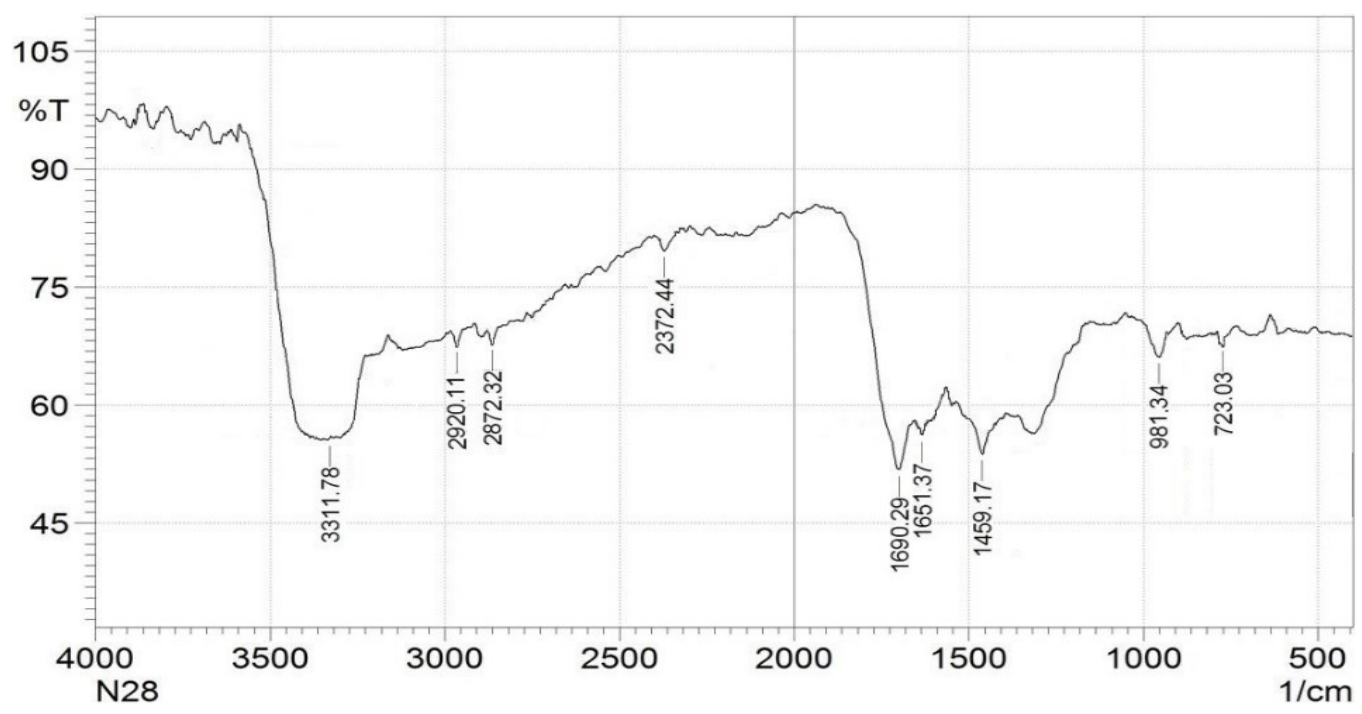

Gambar 7. Spektra inframerah arang aktif dengan aktivator $\mathrm{NaOH}$.

\section{SIMPULAN DAN SARAN}

\section{Simpulan}

Berdasarkan penelitian yang telah dilakukan maka diperoleh kesimpulan bahwa arang aktif dari batang tanaman gumitir (Tagetes erecta) dengan aktivator $\mathrm{NaOH}$ memiliki karakteristik sesuai standar SNI 06-3730-1995. Waktu aktivasi optimum yang diperlukan oleh masingmasing aktivator adalah 24 jam untuk aktivator $\mathrm{NaOH}$. Pada arang aktif dengan aktivator $\mathrm{NaOH}$ didapatkan karakteristik; kadar air 8,40\% $10,53 \%$; kadar zat mudah menguap 9,58\% 14,83\%; kadar abu 4,93\% - 9,07\%; kadar karbon $67,30 \%$ - 77,09\%; daya serap terhadap iodin $682,7875 \mathrm{mg} / \mathrm{g}-758,6874 \mathrm{mg} / \mathrm{g}$; daya serap terhadap metilen biru $124,5861 \mathrm{mg} / \mathrm{g}$ - 124,6092 $\mathrm{mg} / \mathrm{g}$.

\section{Saran}

Berdasarkan dari hasil penelitian yang telah dilakukan, saran yang dapat penulis sampaikan adalah perlu dilakukan penelitian lebih lanjut mengenai hal yang menyebabkan menurunnya karakteristik arang aktif akibat waktu aktivasi yang melewati waktu aktivasi optimum.

\section{UCAPAN TERIMAKASIH}

Penulis menyampaikan rasa terimakasih kepada Bapak Anak Agung Bawa Putra, S.Si., M.Si., Bapak I Wayan Sudiarta, S.Si., M.Si., I Made Sutha Negara, S.Si., M.Si. atas saran dan masukannya. sehingga jurnal ini bias terselesaikan. 


\section{DAFTAR PUSTAKA}

Pari, G. 2004. Arang Aktif Serbuk Gergaji Kayu Sebagai Bahan Adsorben pada Pemurnian Minyak Goreng Bekas. Jurnal Penelitian Hasil Hutan. Bogor. 10(5): 141-149.

Pari, G. Buchari. Sulaeman, A. 1996. Pembuatan dan Kualitas Arang Aktif dari Kayu Sengon (Paraserianthes falcataria) Sebagai Bahan Adsorben. Buletin Penelitian Hasil Hutan. Bogor. 14(7): 274-289.

Pari, G. Hendra D. dan Pasaribu, R. A. 2006. Pengaruh Lama Waktu Aktivasi dan Konsentrasi Asam Fosfat Terhadap Mutu Arang Aktif Kulit Kayu Acia mangium. Jurnal Penelitian Hasil Hutan. Bogor. 24(1): 33-46.

Priyanka, D., T. Shalini, V.K. Navneet. 2013. A Brief Study on Marigold (Tagetes Species): A Review. International Research Journal of Pharmacy. 4 (1): 43-48.

Risfiandi, F. Yusnimar. Helianty, S. 2016. Penentuan Daya Jerap Karbon Aktif dari Tempurung Kelapa Terhadap Ion $\mathrm{Cu}$ (II). Jurnal Online Mahasiswa FTEKNIK. 3(1):1-6.
Sahara, E. Dahliani, N. K. dan Manuaba, I. B. P. 2017. Pembuatan dan Karakterisasi Arang Aktif dari Batang Tanaman Gumitir (Tagetes erecta) dengan Aktivator $\mathrm{NaOH}$. Jurnal Kimia. 11 (2): 174-180.

Sahara, E. Sulihingtyas, W. D. dan Mahardika, I P. A. S. 2017. Pembuatan dan Karakterisasi Arang Aktif dari Batang Tanaman Gumitir (Tagetes erecta) yang Diaktivasi dengan $\mathrm{H}_{3} \mathrm{PO}_{4}$. Jurnal Kimia. 11 (1): 1-9.

Siaka, I M., Febriyanti, N. P. D. Sahara, E. dan Negara, I M. S. 2016. Pembuatan dan Karakterisasi Arang dari Batang Tanaman Gumitir (Tagetes erecta) Pada Berbagai Suhu dan Waktu Pirolisis. Cakra Kimia [Indonesia E-Journal of Applied Chemistry]. 4(2): 168-177.

Sudrajat, R. dan Suryani A. 2002. Pembuatan dan Pemanfaatan Arang Aktif dari Ampas Daun Teh. Buletin Penelitian Hasil Hutan. Bogor. 20(1): 1-11

Utomo, S. 2014. Pengaruh Waktu Aktivasi dan Ukuran Partikel Terhadap Daya Serap Karbon Aktif Dari Kulit Singkong Dengan Aktivator $\mathrm{NaOH}$. Seminar Nasional Sains dan Teknologi 2014. Jurusan Teknik Kimia Universitas Muhammadiyah. Jakarta. 